\title{
The Impact of the Facility Condition and Social Influence on Intention to Use E-Learning
}

\author{
M. Fathur Rahman ${ }^{1}$, Indiri Murniawaty ${ }^{2}$, Widiyanto $^{3}$, Ani Setiyani ${ }^{4}$ \\ \{fathur@mail.unnes.ac.id ${ }^{1}$ \} \\ Universitas Negeri Semarang, Indonesia ${ }^{1,2,3,4}$
}

\begin{abstract}
E-learning is an online learning process that can be accessed anywhere. Apart from ensuring adequate facility conditions, social interaction is also needed to generate the intention to carry out the e-learning process. The purpose of this study is to determine whether there is an influence of facility conditions and social influence on the intention to use e-learning. The research was conducted at Semarang State University in February 2020 to determine the acceptance and usefulness aspects of e-learning. In this study, facility conditions and social influences are determinants and supporters of the intention to use e-learning. Facility conditions and social influence are determining factors in supporting the intention to use e-learning. The data collection technique is in the form of a questionnaire. The data analysis technique uses SEM with the WarpPLS approach, which will test the causality path both on the outer and inner models with an experimental design. This medium is expected to explore the findings of new, more comprehensive, and suitable causal pathways that can be used to interpret data appropriately. The results showed that the facilities' condition was very good, and the support of social influences could increase the intention to use e-learning as an environmentally friendly learning technology.
\end{abstract}

Keywords: Facilitating Conditions, Social Influence, Behavioral Intention, E-learning.

\section{Introduction}

The advancement of information technology in education is very fast and demands that all participate in applying technology. Higher education must be aware of technology and information quickly, accurately, relevant, and accurately in academic activities [1]. Academic quality can be seen from the strategy to achieve competitive advantage and high competitiveness between universities [2]. Technological developments in higher education can support the learning process, one of which is using e-learning. According to Ariani [3], elearning is interactive, attracts attention, and involves students in the learning process. Elearning is a learning method using the internet [4]. The e-learning process is carried out formally according to the learning curriculum, semester learning plans, teaching materials, and learning evaluations that have been compiled and defined.

E-learning is an information technology-based learning technology that can be accepted in the world of education. This acceptance is in the context of improving quality human resources with this information technology's ability to overcome labor problems and economic conditions [5]. E-learning is part of information technology, which is the main requirement for competence in the social and the world of work [6]. According to Horton [7], e-learning is a 
web technology using the internet for the learning process. E-learning is an innovation in sending interactive material with various attributes and digital technology resources in an open, flexible, and distribution learning process [8]. According to Gilbert and Jones [9], Elearning delivers learning materials with electronic media using the internet, broadcast satellites, audio/videotapes, interactive television, CD-ROM, and computer-based training. Furthermore, e-learning is learning using electronic circuits in the form of local area networks, wide area networks, or the internet as the delivery of learning content and interaction or guidance [10].

The e-learning process includes the following components: 1) Relevant content, 2) Learning methods as needed, 3) Media elements as content distribution and learning methods, 4) Guided learning or independent learning, 5) Growing knowledge and techniques new learning objectives [11]. The main components in e-learning include: 1) students, 2) faculty/instructors, 3) facilitators, 4) support staff 5) administrators [12]. Components in elearning that institutions must now consist of 1) learning design, 2) multimedia components, 3 ) internet equipment, 4) computers and storage of tools, 5) connection and service providers, 6) power/management programs, software, 7) services and applications connection [8]. The electronic learning process in the classroom includes: 1) Supplement is an available and selectable electronic learning material 2) Complement is an electronic learning material that is programmed as a complement to learning material that can be accepted in class 3) Substitution is an alternative learning model [13].

Universitas Negeri Semarang has used a learning system using e-learning. In the learning process, using e-learning is expected to support more effective and efficient learning management. E-learning provides convenience in the learning process and does not need to be face to face. Even though e-learning has been applied to theoretical, practical, and assignment courses, e-learning is still difficult to use in the learning process. There are many obstacles, such as lack of information about e-learning, less flexible e-learning support facilities, and other barriers related to social influence and the condition of existing facilities. Social impact is the use of technology-based on encouragement or support from outside other individuals [14], [15]. Before making a decision, a person sometimes considers the expectations that will be achieved. Beliefs provide encouragement or support in forming intentions. The social influence will affect intent [15][16].

Meanwhile, the facility's condition is a person's perception of infrastructure, resources, and techniques in operating technology [15][17]. The intention is something that is expected by a certain behavior [18]. According to Fishbein [19], the purpose is an effort made to achieve a goal. The intention is the desire to carry out a behavior, while the behavior is real action on that desire [20]. The stronger the insults or expectations, the stronger the intention to display a behavior [21]. The use of e-learning aims to socialize better learning system improvements.

\section{Research Methods}

This research was conducted at the Faculty of Economics, State University of Semarang. The data used are primary data obtained from questionnaires to respondents consisting of students and documentation [22]. Sampling using a proportionate stratified random sampling method because the population is not homogeneous. According to Sugiyono [23], proportionate stratified random sampling is used if the community has members who are not 
homogeneous and have proportionate strata. The sample used was 280 respondents. According to Ferdinand [24], sampling is based on Krijcie and Morgan tables with 1000-1100 respondents. Reliability testing can use the indicator value by squaring each indicator. An indicator is said to be reliable if the hand is greater than 0.7 [25]. The validity test can be seen from the average variance extracted (AVE) value of the latent variable. It is valid if the latent variable has an average variance extracted (AVE) value greater than 0.5 [26].

There are independent variables in this study, namely social influence and facility conditions, while the dependent variable is intention. The data analysis technique in this study, used the Structural Equation Model (SEM). SEM is a technique that combines multiple regression and factor analysis to estimate the dependency relationship simultaneously [27]. SEM is widely used to calculate variance, covariance analysis, multiple regression, factor analysis, path analysis, simultaneous equations and nonrecursive modeling, latent, and multilevel curve modeling [28]. SEM can identify constructs and influence measures that have identified dimensions [29].

\section{Result and Discussion}

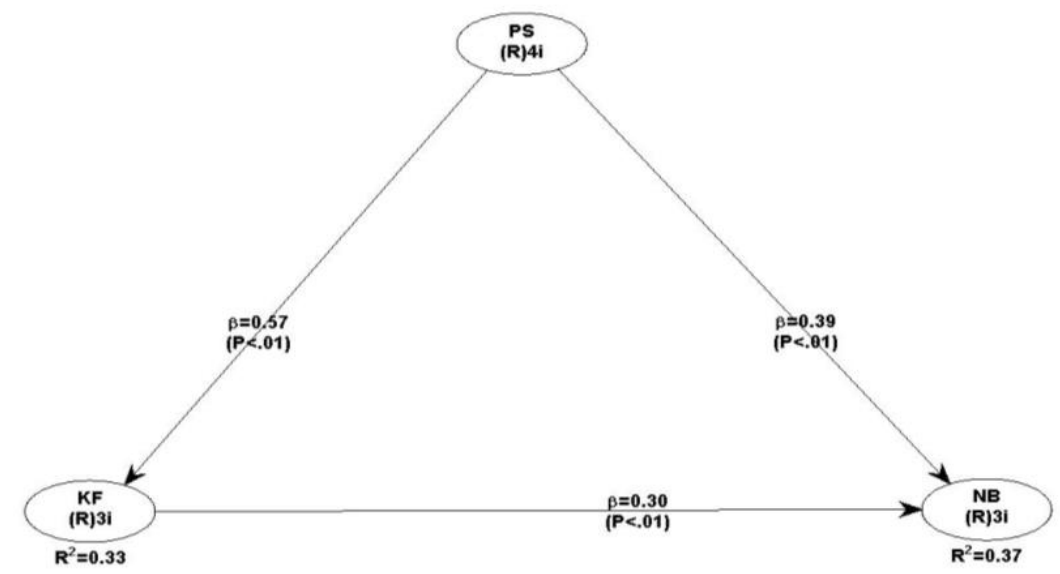

Fig. 1. Research Model in WarpPLS

Testing the reliability using SEM WarpPLS it is necessary to check indicators as a measurement tool for latent variables. Reliability can be accepted if the indicator is more than 0.7 [25]. Each indicator can be calculated by running the PLS algorithm using WarpPLS 6.

Table 1. Reliability

\begin{tabular}{cccc}
\hline Latent Variable & Indicator & Value Reliability Indicator & Note \\
\hline \multirow{3}{*}{ Social Influence } & PS 1 & 0.800 & Reliability \\
& PS 2 & 0.862 & Reliability \\
\cline { 2 - 4 } & PS 3 & 0.712 & Reliability \\
& PS 4 & 0.710 & Reliability \\
\hline Condition Facilities & KF 1 & 0.853 & Reliability
\end{tabular}




\begin{tabular}{llll}
\hline & KF 2 & 0.720 & Reliability \\
& KF 3 & 0.820 & Reliability \\
\hline \multirow{3}{*}{ Intentions Using } & NB 1 & 0.744 & Reliability \\
& NB 2 & 0.710 & Reliability \\
& NB 3 & 0.707 & Reliability \\
\hline
\end{tabular}

Source: Researchers Processed Data, 2020.

Based on table 1., the social influence variable has four indicators: getting the predicate reliable on all hands. There are three indicators in the facility condition variable with a reliable predicate for each indicator. The intention to use e-learning has three arrows, and all of them get reliable predicates. It is said to be valid if the average variance extracted (AVE) value in the variable is greater than 0.5 [26].

Table 2. Average Variance Extracted (AVE)

\begin{tabular}{ccc}
\hline Latent Variable & Average Variance Extracted (AVE) & Note \\
\hline Social Influence & 0.554 & Valid \\
Condition Facilities & 0.593 & Valid \\
Intentions Using & 0.508 & Valid \\
\hline
\end{tabular}

Source: Researchers Processed Data, 2020.

Based on Table 2, the social influence variable is valid, with a value of 0.554 . The Average Variance Extracted (AVE) value of 0.593 is said to be useful for the variable facility conditions, and the intention to use e-learning gets an Average Variance Extracted (AVE) value of 0.508 with a valid predicate. The following is a table 3 of the results of the research hypothesis:

Table 3. Path Coefficients

\begin{tabular}{cccc}
\hline Variable & Social influence & Facility conditions & Intention \\
\hline Social Influence & & & \\
Facility Conditions & 0.575 & 0.299 & \\
Intention & 0.385 & Source: Researchers Processed Data, 2020.
\end{tabular}

Based on table 3., it shows that the influence of the variable on the condition of the facility is 0.575 , the coefficient of the impact of the social influence variable on the intention to use e-learning is 0.385 , and the influence coefficient of the effect on the choice to use elearning is 0.299 .

Table 4. P-Values

\begin{tabular}{|c|c|c|c|}
\hline Variable & Social influence & Facility conditions & Intention \\
\hline Social Influence & & & \\
\hline Facility Conditions & $<0.001$ & & \\
\hline Intention & $<0.001$ & $<0.001$ & \\
\hline
\end{tabular}

Based on table 4 , the p-value shows the influence of the social influence variable on the condition of the facility of $<0.001$, the p-value shows the impact of the social influence 
variable on the intention to use e-learning of $<0.001$, and the p-value is the effect of the facility condition on purpose using e-learning for $<0.001$.

Table 5. Hypothesis

\begin{tabular}{ccccc}
\hline \multicolumn{2}{c}{ Relationship Between Variables } & Coefficients & P-Value & Note \\
\hline Social Influence & Facility Conditions & 0.575 & $<0.001$ & Highly Significant \\
Social Influence & Intention & 0.385 & $<0.001$ & Highly Significant \\
Facility Conditions & Intention & 0.299 & $<0.001$ & Highly Significant \\
\hline
\end{tabular}

Source: Researchers Processed Data, 2020.

Based on table 5, the results of the research hypothesis that there is a variable influence of social influence on the condition of the facility with a value of $p<0.001$, so it gets a very significant predicate with a coefficient of 0.575 . This shows that the greater the social influence, the better the condition of the facilities. The variable of the impact of the colonial effect on the intention to use e-learning with a p-value of $<0.001$, then it gets a very significant predicate with a coefficient of 0.385 . This shows that the greater the social influence of eating, the greater the intention to use e-learning. The effect of facility conditions on the choice to use e-learning with a p-value of $<0.001$, then getting the predicate is very significant with a coefficient of 0.299 . This shows that a good improvement in the facility's condition will further support the use of e-learning intentions.

\subsection{Discussion}

\subsubsection{Social Influence on Facility Conditions}

From the research results that have been carried out, the social influence on the facility's condition shows a positive coefficient of 0.575 with a p-value of $<0.001$ and obtains the predicate of highly significant. This indicates that the social influence on the state of the facility has a positive and significant effect. The use of e-learning has received support from the campus and lecturers and has received a touch of changes in the conditions of e-learning supporting facilities. The improved social influence will improve existing facilities. They are supported by Ismail's [30] study of the socio-economic changes experienced by the Karangploso community due to the construction of tourism facilities. The environment affects learning conditions [31].

\subsubsection{Social Influence on Intention to Use E-Learning}

From the research results, it was found that the social influence on the intention to use elearning was 0.385 with a p-value of $<0.001$ and got the predicate of highly significant. This shows that the social impact on the choice to use e-learning has a positive and significant effect. The increasing social influence, the more the intention to use e-learning. Social influence is related to a person's perception, who thinks someone should do a certain behavior. High social influence results in high intentions in using new technology and systems. Someone who has no experience using technology tends to seek information from the surrounding environment, such as family, friends, and social media, to affect the data obtained. The use of e-learning has received support from various parties, both campuses, and lecturers, to use e-learning. It is proven that many lecturers have conducted lectures online, not only giving assignments or chatting.

The results of this study are supported by Destaningrum [32], showing a positive and significant influence between the social impact on intention to use e-learning. The greater the 
social impact, the greater the choice to use e-learning. Like Permana's research [33], there is social influence on the intention to use positive and significant applications, the more social influence increases, the more the choice to use the application. The same result states that social influence positively and significantly affects user intention [34].

\subsubsection{The Effect of Facility conditions on Intention to Use E-learning}

From the research results that have been carried out, there is an effect of facility conditions on using e-learning of 0.299 with a p-value of $<0.001$ and obtaining the predicate as highly significant. This shows that the social influence on the intention to use e-learning has a positive and significant effect. The condition of the facility is related to internal and external perceptions which include self-confidence in technological facilities, environmental factors make an action to be carried out and how far innovation is perceived consistently according to potential needs and experience. The use of media in the form of e-learning can be exciting to learn and interact directly. The use of e-learning has gained very adequate facilities in the form of very fast Wi-Fi to be used.

This study's results are the same as those conducted by Haryanto [35], showing a positive and significant effect between the facility's condition on the intention to use. The state of adequate facilities makes it easier for users to access the Edmodo online learning system. This medium is evidenced by the hypothesis that there is a positive and significant effect between falsities' condition on the intention to use Edmodo [36]. This medium is also supported by Radiansyah's research [37] that the facility's state has a significant effect on the intention to use T-Cash. The facility's condition increases, so the choice to use will improve for application users [33].

\section{Conclusion}

On the results of testing the hypothesis that social influence has a positive and significant effect on the facility's condition. The social impact affects the intention to use e-learning positively and significantly. The facility condition is stated positive and meaningful towards the choice to use e-learning.

\section{References}

[1] V. S. Moertini, Pengembangan Sistem Dan Sarana Teknologi Informasi Untuk Perguruan Tinggi Indonesia. Bandung, 2008.

[2] T. Haryanto and S. Riyanarto, "Comparation of CobiT Maturity Model and Structural Equation Model for Measuring the ALignment between University Academic Regulations and Information Technology Goals," Int. J. Comput. Sci. Netw. Secur., vol. 10, no. 6, 2010.

[3] D. Ariani, "Komponen Pengembangan E-learning," J. Pembelajaran Inov., vol. 1, no. 1, pp. 5864, 2018

[4] D. E. Hartley, Selling E-Learning. America: American Society for Training and Development, 2011.

[5] I. Inayat, R. Ul Amin, Z. Inayat, and S. S. Salim, "Effects of collaborative web based vocational education anda training (VET) on learning outcomes," Comput. Educ, vol. 68, pp. 153-166, 2013.

[6] K. Loogma, J. Kruusvall, and M. Umarik, "E-learning as Innovation: Exploring Innovativeness of the VET Teacher Community in Estonia," Compuct. Educ., vol. 58, pp. 808-817, 2012. 
[7] W. Horton and K. Horton, E-learning Tools and Technologies: A Consumer's Guide for Trainers, Teachers, Educators, and Instructional designers. Jhon Wiley \& Sons, 2003.

[8] B. H. Khan, Managing e-learning: Desaign, Delivery, Implementation, and Evaluation. IGI Global, 2005.

[9] M. G. Gilbert, \& Jones, "E-learning is e-normous," Electr. Perspect., vol. 26, no. 3, pp. 66-82, 2001.

[10] J. Kumar, "Aplikasi E-learning dalam Pengajaran dan Pembelajaran di Sekolah Malaysia," 2002.

[11] S. Maudiarti, "Penerapan E-Learning Di Perguruan Tinggi," Perspekt. Ilmu Pendidik., vol. 32, no. 1, pp. 51-66, 2018.

[12] H. T. Gottschalk, "Distance Education: An Overview," 1995.

[13] S. Siahaan, Analisis Motif Mengajar Guru dalam Membangun Pemahaman Instrumental dan Pemahaman Relasional Siswa dengan Membangun Skema Pemecahan Masalah Berdasarkan Model Argumentasi Toulmin. Bandung: SPs. UPI, 2002.

[14] S. Brown and V. Venkatesh, "Model of Adoption of Technology in Households: A Baseline Model Test Household Life Cycle," MIS Q., vol. 29, no. 3, pp. 399-426, 2005.

[15] S. Wang, J. Fan, D. Zhao, S. Yang, and Y. Fu, "Predicting consumers intention to adopt hybrid electric vehicles: using an extended version of the theory of planned behavior model," Transportation (Amst)., vol. 43, no. 1, pp. 123-143, 2016.

[16] V. Venkatesh, M. G. Morris, G. B. Davis, and F. D. Davis, "User Acceptance of Information Technology: Toward a Unified View," MIS Q., vol. 27, no. 3, pp. 425-478, 2003.

[17] V. Venkatesh, J. Y. Thong, and X. Xu, "Consumer Acceptance and Use of Information Technology: Extending The Unifed Theory pf Acceptance and Use of Technology," MIS Q., vol. 36, no. 1, pp. 157-178, 2012.

[18] I. Ajzen, The Theory of Planned Behavior. In P. A. M. Lange, A. W. Kruglanski \& E. T. Higgins (Eds.), vol. 1. London, UK: Sage, 2012.

[19] M. Fishbein, I. Ajzen, D. Albarracin, and R. C. Hornik, Prediction and change of health behavior: applying the reasoned action approach. Mahwah, N.J: Lawrence Erlbaum Associates, 2007.

[20] I. Arisudana, "Intensi Berbagi Pengetahuan ditinjau dari Ekstraversi, Sikap, Norma Subyektif, dan Kontrol Perilaku yang Dipersepsikan," PPs UGM, 2009.

[21] H. M. Jogiyanto, Sistem informasi keperilakuan. Yogyakarta: Andi Offset, 2007.

[22] S. Margono, Metodologi Penelitian Pendidikan. Jakarta: Rineka Cipta, 2010.

[23] Sugiyono, Metode Penelitian Administrasi. Bandung: Alfabeta, 2012.

[24] A. Ferdinand, Metode Penelitian. Semarang: UNDIP Press, 2010.

[25] J. Hulland, "Use of Partial Least Squares (PLS) in Strategic Management research: a review of four recent studies," Strateg. Manag. J., vol. 20, no. 2, pp. 195-204, 1999.

[26] R. P. Bagozzi and Y. Yi, "On the evaluation of structural equation models," J. Acad. Mark. Sci., vol. 16 , no. 1, pp. 74-94, 1988.

[27] I. Hair, R. Anderson, and R. Tatham, Multivariate Analysis 5 Edition. Prentice Hall International, Inc, 1998.

[28] B. G. Tabachnick and L. S. Fidell, Using Multivariate Statistics. Boston: Allyn \& Bacon, 2007.

[29] A. Ferdinand, Structural Equation Modelling dalam Penelitian manajemen. Semarang: AGF Press, 2014.

[30] M. K. J. Ismail, M. K. Mawardi, and M. Iqbal, "Analisis Dampak Sosial Ekonomi Pengembangan Pariwisata Kota Batu Bagi Kawasan Sekitar (Studi pada Kecamatan Karangploso Kabupaten Malang)," J. Adm. Bisnis, vol. 51, no. 1, 2017.

[31] A. Budiarti and S. Wahyuni, "Hubungan tingkat penerapan peraturan, Lingkungan Dan Fasilitas Dengan Kondisi Belajar Di Asrama AKBID Wira Husada Nusantara Malang," Biomed Sci., vol. 5, no. 1, pp. 1-6, 2017.

[32] D. Destaningrum, Suprapto., and N. H. Wardani, "Analisis Faktor Penerimaan Penggunaan Elearning SMA Negeri Di Kota Blitar Menggunakan Unified Theory Of Acceptance And Use Of Technology (UTAUT),” J. Pengemb. Teknol. Inf. dan Ilmu Komput., vol. 2, no. 2, pp. 723-732, 
2018.

[33] G. P. L. Permana and L. P. K. Dewi, "Analisis Penerimaan Dan Penggunaan Aplikasi OVO Dengan Menggunakan Unified Theory Of Acceptance And Use Of Technology (UTAUT) Di Kota Denpasar," J. Ilm. Akunt. dan Bisnis, vol. 4, no. 2, 2019.

[34] N. Rahmatillah and R. N. Fitri, "Analisis Pengaruh Perilaku Penggunaan Teknologi Fintech Pada Generasi Millenial Di Kota Bandung," J. Chem. Inf. Model., vol. 53, no. 9, pp. 1689-1699, 2018.

[35] Haryanto, "Kajian Implementasi Pembelajaran Berbasis E-learning Dengan pendekatan Menggunakan Unified Theory Of Acceptance And Use Of Technology (UTAUT) (Studi Kasus pada SMP Al-Amanah Kota Tangerang Selatan),” J. Khatulistiwa Inform., vol. 1, pp. 14-20, 2017.

[36] S. Taqwatika, K. Agustini, and P. A. Suyasa, "Analisis Penerimaan Sistem Pembelajaran Online Edmodo Menggunakan Menggunakan Unified Theory Of Acceptance And Use Of Technology (UTAUT) Studi Kasus: Kelas IX Di SMP Negeri 1 Singaraja,” Kamapati, vol. 8, no. 2, 2019.

[37] E. Radiansyah and M. Ariyanti, "Analisis Pengaruh Tcash Menggunakan Unified Theory Of Acceptance And Use Of Technology (UTAUT2) Studi Pada Mahasiswa Pengguna Tcash Di Universitas Telkom," e-proceeding Manag., vol. 4, no. 1, pp. 281-290, 2017. 